\title{
Contribution of Physiology and Biochemistry to Progress in Aquaculture
}

\author{
Hubert J. CECCALDI*
}

Physiological and biochemical methods and techniques are used to study biological processes at different levels of organization of living matter.

Normal physiological processes of marine organisms caught in natural environment or maintained under constant external conditions have been studied in numerous scientific works. Nutrition, respiration, reproduction and metabolism for instance, are physiological functions more or less extensively known in algae, fishes, molluscs and crustaceans, among other phyla, generally depending on their economical interest.

Less studied are the physiological variations characterizing these species under different external conditions, systematically fixed, one by one, or by groups, or under determined variations of these environmental factors. Ecophysiology provide considerable information on the ecological characteristics of the studied species in nature, where temperature, photophase, light intensity, salinity, etc. . . vary simultaneously in a non-programmed manner. The effects and consequences of each of these factors considered individually must be evaluated and measured in order to ascertain the importance of each one in nature and for each physiological function.

The scientific information obtained in these studies is easily made use of in aquaculture, especially with intensive techniques.

The normal biochemical characteristics of marine organisms caught in natural environment or maintained under constant external conditions have sometimes been of interest for laboratories specialized in pure or physiological biochemistry. Some descriptive works in structural biochemistry, concerning the detailed composition of marine organisms, are available. The former vary in number and importance, depending on the different phyla. Enzymes characteristic of each physiological function, i.e. digestive enzymes in the nutritional function, and enzymes of intermediary metabolism for instance are much less known than in mammals, and sometimes not known at all in certain entire zoological groups.

Biochemical variations of these species under systematically fixed or experimentally varying external conditions have been much less developed and are much less known, especially in marine organisms. This scientific area, which can be called ecobiochemistry, will provide a fundamental explanation of the physiological functions of aquatic species, especially those reared in aquaculture.

The physiological and biochemical rhythmicity of these species internal or imposed, circadian, seasonal, annual, or depending on the molting cycles in arthropods, have to be studied in detail in order to enhance intensive aquaculture and automatization of the related techniques.

The relationship between the variable physiology and biochemistry of the hosts and their parasites, where interesting results have recently been obtained, have to be developed in order to gain an understanding of the processes of infestation, the reciprocal complementarities of the hosts and the parasite, and to improve the prevention and treatment of the hosts. Such a scientific area could be called ecophysioparasitology. Similarly, ecophysiopathology deals with the internal and external conditions of disease apparition.

The development of ecophysiology and ecobiochemistry needs interdisciplinary teams made up of marine biologists, physiologists and biochemists, working closely with specialists in aquaculture and development. 


\section{Introduction}

Biological systems include phenomena and reactions situated at various organizational levels of living matter: ecosystem mechanisms, community equilibriums, biology of individuals, physiology of organs, cell metabolism, functioning of cellular organelles, macromolecule reactions and synthesis or catabolism of small molecules which are characteristic or not of living matter.

The phenomena which occur at each of these organizational levels automatically influence the other levels, particularly the closest.

The phenomena and their interactions are very strongly integrated as they are interdependant of each other. In particular, the reaction which occur at the macromolecular level in polyenzymatic systems govern the functioning of the cellular organelles or membranes in which they are included. These latter, in turn, control the metabolism of the whole cell. The physiology of the organs and consequently the biology of the individuals are only consequences. In the field of aquaculture, it is absolutely indispensable to have a good knowledge of the biology and physiology of the animals or plants to be reared, in order that these latter may be placed in the most favourable environmental conditions and be supplied with the food and energy for optimal performance.

Thus the growth and reproduction of the species chosen may be efficiently controlled. The physiological and biochemical characteristics of the species to be reared must thus be ascertained precisely, so that their biology may be thoroughly investigated and traditional rearing may be improved with as little error as possible and, above all, new species may be successfully obtained in aquaculture.

Important works on the physiology of marine organisms have been realized to date and considerable scientific information is already available. However, few of these works are concerned with the variations of physiological functions when the characteristics of the external medium vary. These differential and comparative studies which take into account the close relations of the physiology of marine organisms and their ecology-often designated ecophysiology-still suffer from considerable gaps and much research work should be undertaken.

In another connection, scientific investigations concerning the chemical characteristics of marine organisms have been carried out in specialized biochemical laboratories. However, relatively few specific investigations have been undertaken concerning variations of biochemical characteristics when the physical conditions of the external medium vary and using species for aquaculture, or other marine species. This constitute a vast field of new research which will lead to the forgoing of new concepts in the fundamental field and interesting application in aquaculture.

\section{Physiological Functions}

The oldest and most classical studies concern the nutritional needs of species of interest for aquaculture. The alimentary requierements as concerns proteins, carbohydrates, lipids, mineral salts and vitamins, are sometimes known in some detail, but they should be established for each of the species considered.

Optimal protein content; the best growth rates were observed for amino acid values which differed greatly from one species to another, and not only within a single zoological taxon, but often even within the same family or the same genus. Thus, in the Penaeidae, different authors have been able to show that the optimal protein content for Penaeus japonicus, considered to be cannibalistic, is high, between $50 \%{ }^{1)}, 60 \%$ and even $70 \%{ }^{3}$. In contrast, the optimal content is less important for other omnivorous species, for instance $70 \%$ for $\boldsymbol{P}$. duorarum ${ }^{4}$, although it is less, $39-50 \%$ for $P$. kerathurus $^{5)}, 28-32 \%$ for $P$. setiferus ${ }^{8)}, 22.5$ $30 \%$ for $\boldsymbol{P}$. aztecus ${ }^{7)}$. Other results were reviewed by several authors ${ }^{8,8)}$.

In other taxons such as Palaemoninae ${ }^{10-14)}$ or Crangonidae ${ }^{10,15-17)}$ for instance, there is the same situation and diversity of results.

Essential amino-acid requierements; these must be established both qualitatively and quantitatively and with some degree of accuracy. Quantitative assessments have been undertaken in the crayfish Astacus astacus ${ }^{18)}$, in sole and plaice ${ }^{10)}$, in the shrimp Palaemon serratus ${ }^{20)}$, in the shrimp Penaeus aztecus ${ }^{21)}$, in the freshwater shrimp Macrobrachium ohione ${ }^{22)}$, in the abalone Haliotis ${ }^{28)}$ and in the shrimp Metapenaeus monoceros ${ }^{24)}$. It has been shown that the essential amino acids were most likely valine, methionine, isoleucine, leucine, phenylalanine, lysine, histidine, arginine, threonine and tryptophane.

The characteristics of these problems have been reviewed by several authors ${ }^{25-80}$. Protein and amino acid supply in the food should correspond 
to the characteristic nutritional needs of the species reared. Where this is not the case, the excess nitrogen is excreted. In traditional studies for ascertaining the nutritional amino acid needs of reared animals, it has been shown in shrimps such as Penaeus japonicus ${ }^{\mathrm{g})}$, Palaemon serratus ${ }^{312}$ and fish such as carp ${ }^{32}$ that, when purified amino acids are added to the compounded diets, growths are smaller than with foods containing proteins alone. The method of protein well balanced in amino acids or artificially enriched ${ }^{332}$ seems to be a means for the future, both in fundamental research in enzymology and in aquaculture, for obtaining the chemical equilibrium ${ }^{34)}$ and for attaining good growth $^{35)}$.

Carbohydrates: The energetic metabolism of marine animals, especially invertebrates, is largely based on lipids whereas in land animals, carbohydrates, especially polysaccharides, are essentially involved. These latter are extracted from Graminacea grains and mainly from starches used for reared animals. Marine animals dispose of practically no starch in the marine environment, and seaweed is their only source of plant polysaccharides. Carbohydrates of high molecular weight require numerous hydrolysis reactions, each of which consumes metabolic energy in order to obtain molecules of more or less sizeable lengths, and which are more or less rapidly utilizable. Conversely, carbohydrate molecules of low molecular weight-mono, di or tri saccharides-seem to be easily assimilable, but when mixed with foods in pellets or in paste, they are partially lost. Although a number of attempts have been made on Palaemon serratus $^{36)}$ and in Peneids ${ }^{6,37,38)}$, little information is available about the general $P$. japonicus, aspects of carbohydrate nutrition of Crustacea. In $P$. japonicus their best results were obtained with diets containing $19.5 \%$ maltose $^{38)}$ and in Metapenaeus monoceros, $15 \%$ saccharose ${ }^{\theta)}$. Optimal carbohydrate contents in the foods are relatively low compared with those of land animals.

Lipids: Investigations with polyunsaturated fatty acids in several laboratories have shown that in feeding trials certain fatty acids such as linoleic

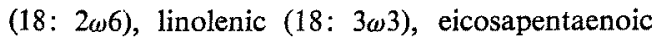
(20:5 53$)$ and docosahexaenoic $(22: 6 \omega 3)$ acids are essential for fish growth. Thus, similar results were obtained with chinook salmon ${ }^{40)}$, rainbow trout or Salmo gairdneri ${ }^{41-40)}$, carp Cyprinus carpio $^{50,51)}$, red sea bream Pagrus (=Chrysophrys) major $^{52-54)}$ and turbot Scophthalmus maximus ${ }^{55)}$.
Several French-Japanese scientific works have shown that in Penaeus japonicus ${ }^{50,57)}$ the best growth and the highest molting rates are obtained when the food contains a high level of $\omega 3$ polyunsaturated fatty acids, for instance fish oils ${ }^{58)}$, marine molluscs oils ${ }^{67,(6)}$, or marine crustaceans oils ${ }^{80)}$.

The mortality of red sea bream larvae is rather high when they are fed with newly-hatched nauplii, the dietary value of the nauplii is effectively improved by feeding them with marine Chlorella and the so-called $\omega$-yeast, i.e. Saccharomyces cerevisiae grown in a culture medium containing $15 \%$ cuttlefish liver oil for $24 \mathrm{~h}$. These essential fatty acids are the principal factor in the food value of Artemia for fish ${ }^{61)}$.

Brachionus plicatilis fed with $\omega$-yeast, rich in essential fatty acids, give good results concerning growth of red sea bream larvae ${ }^{62)}$. Similar results have been obtained on the growth of a fish, Plecoglossus altivelis ${ }^{\text {(3) }}$.

The conversion of linolenic acid (C 18: 3w3) into long chain polyunsaturated fatty acids such as docosahexaenoic acid C 22: $6 \omega 3$ ), does not occur in the same way in freshwater and salt water fish. This conversion rate was much smaller in salt water fish such as black sea bream Mylio macrocephalus, opaleye Girella nigricans or striped mullet $M$ ugil than in fresh water fish, particularly rainbow trout Salmo gairdneri ${ }^{(4)}$.

Phospholipids also play a considerable part in this field. The phospholipid composition of marine animals is sometimes well defined, but knowledge of their metabolism is rudimentary ${ }^{85)}$. Phospholipids extracted from Bivalvia belonging to the genus Tapes have been used as an element of compounded diets in Penaeus japonicus. ${ }^{59}$ The most effective component is firstly lecithin, and then cephalin. Tapes phospholipids, which represent almost $65 \%$ of the total lipids of the mollusc, improve the weight gain of Penaeus, but soybean lecithin and egg lecithin have hardly any effect. In juvenile lobsters, Homarus americanus ${ }^{6 \theta)}$, it has been shown that soy lecithin plays an efficient role in the survival rate, and that choline, a constituent of lecithin, is probably not the active component.

Sterols also play an important role in the nutritional requierements of Crustaceans ${ }^{87.88)}$, because they participate in membrane structures and are precursors of molting hormone ecdysones.

Crustaceans are not able to synthesize crustecdysone de novo, and need sterols to synthesize such molecules through cholesterol ${ }^{69,70)}$. It is 
vely importani to know the metabolic pathways in this family of molecules ${ }^{71-73)}$, so that appropriate and low price sterols can be added in compounded diets ${ }^{74}$.

Other physiological functions in marine animals have been studied in some detail, i.e. respiration with gill physiology ${ }^{75-78)}$ and blood pigment properties, hemoglobins ${ }^{77)}$, and hemocyanin ${ }^{78)}$. The mecanisms of excretion, in relation to the metabolism and characters of the aquatic environ$\operatorname{ment}^{80,81)}$, and osmoregulation ${ }^{82-84)}$, are beginning to be understood.

\section{Physiological Cycles}

Physiological parameters change even in stable environmental conditions, due to internal cycles such as circadian rhythms, molting cycles in arthropods, or evolution of physiology during growth.

It has been shown for instance that an endogenous rhythmicity is associated with larval hatching in the lobster Homarus gammarus ${ }^{85)}$. The hour of hatching seems to be fixed as early as at the egg phase, and this is of importance in aquaculture.

Behaviour of Penaeids ${ }^{88}$ as well as colour of Decapods $^{87,88)}$ are also dependent on endogenous rhythms.

Survival and resistance to extreme temperatures are not the same at different ages of the same animal and after acclimation to temperatures. ${ }^{89}$ ) Physiological characteristics evolve during growth and there is a capacity for adaptation to low or high temperature which influences the results of physiological studies.

During larval development of Crangon septemspinosa and Palaemon serratus, important changes occur in the composition of the larvae $e^{90,812}$. Total concentration increases from the first stage to the post larval phase, particularly at the fourth stage. A strong drop occurs at the last larval stage; the so-called essential amino-acids show no great variation contraly to the non-essential ones.

This increase of free amino-acid composition should be compared with the increase of proteasic activities of the larvae which occurs between larval stages 3 and 4 .

High concentration of free amino-acids enhances osmoregulatory capacities during a period of migration behaviour. The qualitative importance of essential amino-acids ${ }^{20)}$ shows the major role of these compounds as a limiting factor for the growth and migration of the larvae. Lipid synthesis and sterol metabolism are not a continuous process during crustacean growth; this process varies according to the molting $\mathrm{cycle}^{82-95)}$.

\section{Ecophysiology}

The natural and unavoidable cycles of physiological functions are more or less perturbed when environmental factors change, or in a changing environment under variable conditions, or in experimental conditions.

In the red sea bream, the influence of variations of temperature have been studied ${ }^{\text {(a) }}$. Hemoglobin content, haematocrit value, serum cortisol level and glucose level increase with temperature. Physiological reactions are rather complex and interdependant.

When acclimatized to different temperatures, the composition of lipids and fatty acids of abdominal muscle of Palaemon serratus show important variations. Total lipid level and polyunsaturated fatty acids exhibit an inverse relationship with temperature ${ }^{\text {t7). }}$.

Quantitative and qualitative seasonal variations of fatty acid composition in Penaeus japonicus have shown that lipid content of the prawn increases from May to November. A curious fact, until now unexplained, should be pointed out: highest lipid rate is observed in November in males and in October in females ${ }^{88)}$. The relative importance of temperature, light and food on lipid content, has not been clearly identified.

In yellowtail Seriola quinqueradiata ${ }^{99)}$ the quantity of food eaten diminishes with decrease in temperature.

The adaptabilities to variation of salinity depend on temperature ${ }^{100-108)}$, not only in adults and juveniles, but also in larvae and fertilized eggs, as already shown in the fish Sillago sihama ${ }^{108)}$. Effects of salinity and temperature have been studied in the larvae of mud crab Rhithropanopeanus harrisi ${ }^{107}$, or in the yellowtail flounder Limanda ferruginea ${ }^{108)}$.

Influence of photoperiod and intensity of light has been investigated in post-larvae and juveniles of the fish Mylio macrocephalus ${ }^{108)}$. The best growth and survival of post-larvae reared in five different light intensities were obtained at 3000 1x. Length of photoperiod does not have the same effect on food consumption and on growth at different ages of the animal; the longer photoperiod increased food consumption and growth of postlarvae, but did not increase those of juveniles of 
this species. Red and orange colours have been shown to be very harmful for the growth and the survival of crustacean larvae ${ }^{110,111)}$.

Lipid composition of Peneids caught in the Gulf of Mexico, Penaeus setiferus, $P$. aztecus and $P$. duorarum varies during the different months of the year $^{112)}$. When the variations in fatty acid levels were compared to the temperature of the water, there was a 2 month lag period between a change of water temperature and the corresponding variations in fatty acid composition. This slow modification of the shrimp fatty acids suggests that the changes are effected through the food chain rather than by endogenous adjustment to a change in sea water temperature.

In this respect, a few works have been carried out concerning the qualitative variations of the components of the natural communities throughout the season. These components may be considered as elements in the food chain, with an annual stereotyped variation of their chemical composition. Such a qualitative variation may be simulated in aquaculture.

A simulation of optimal salinities and temperatures, for each larval stage in the rearing tanks will greatly improve the survival rates and the conditions of the larvae: excretion products will be considerably reduced.

Several works have suggested that maximal growth of an aquatic animal should occur in water with salinity isosmotic to internal medium, since the animals would not be expending energy in osmotic processes. Growth and osmoregulatory studies, however, show that this is not true in the fresh water shrimp Macrobrachium ${ }^{113}$, but seems to be valid for certain fishes. There is an evolution of physiological needs during different larval stages $^{114)}$, and this concept has to be developed, particularly in larval migrating species, where natural variations of salinity may be simulated during larval growth.

Free amino acids play an important role in osmoregulation processes during variations of salinities, and during osmotic stresses ${ }^{115-117)}$.

Free amino acid content and related compounds increase during development of rainbow trout Salmo gairdneri: concentrations of glycine, alanine, histidine, taurine, anserine and creatine increase notably, while those of glutamine, aspartic and glutamic acids decrease until hatching ${ }^{118)}$.

Nitrogen excretion chiefly depends on the salinity of the medium where animals are cultured ${ }^{11 \theta}$. It also depends on the food composition given to these species, as has been shown in the carp ${ }^{120)}$. Unbalanced food, especially in nitrogenous components, provokes different kinds of excretion processes and different figures of excretion products. They have to be known in detail to predict pollution of tanks where animals are growing, and also to predict the bacterial population which may grow in these tanks.

\section{Limits of Ecophysiological Adaptation}

The characteristics of the internal medium of marine animals, excepting marine mammals in some ways, vary as a function of external environmental factors. Their homeostasis is weak or even very weak and the cell of the different organs contained in this variable medium must possess varied intracellular regulation functions in order to adapt to a changing microenvironment.

When the conditions of the external medium vary, the animal adjusts, within certain limits, the characteristics of its internal medium to the constraints imposed by the external environment and the cells must adapt to it. When external conditions vary strongly, the limits of internal adjustment are reached and the composition of the internal medium cannot exceed certain values. If these characteristics exceed the regulation capacity of their intracellular physiology, they become jeopardized and die eventually causing the death of the entire individual. In the case of brackish water species, such as Macrobrachium, salt excretion presents some pecularities: urine, produced by the antennal gland, is not isosmotic to hemolym$\mathrm{ph}^{121)}$, but hypoosmotic. In Penaeus setiferus and $P$. stylirostris reared at salinities ranging from $10 \%$ to $40 \%$, urine is hypoionic to the hemolymph with respect to sodium, and isoionic to hemolymph with respect to chloride ${ }^{122)}$. It has to be known if the ionic composition of sea water or brackish waters are the most appropriate for the success of different species in aquaculture.

Combinations and responses of marine poikilotherms to environmental factors such as temperature, salinity and oxygen, have been reviewed ${ }^{104,123)}$; considering their great complexity, intense efforts have to be carried out in this whole field to help aquaculture.

\section{Biochemistry of Cultured Species:}

Knowledge concerning several key molecules has to be developed, particularly in digestive en- 
zymes, blood protein, characteristic enzymes involved in glucose and fatty acid oxidation in different animal phyla ${ }^{124)}$.

Despite their fundamental importance, digestive enzymes of marine animals have not been studied with sufficient attention, except in the noticeable cases of the crayfish Orconectes virilis and other Crustacea $^{126,127)}$, in the crab Carcinus maenas ${ }^{128,12 \theta)}$ and the crayfish Astacus leptodactylus and $A$. fluviatilis $^{130,131)}$.

Trypsin or trypsin-like enzymes ${ }^{132)}$ have been demonstrated in Penaeus setiferus hepatopancreas, with properties close to mammalian trypsin M.W. $=24000$ and same inhibitors. It seems that there is no zymogen form.

More recently, some detailed works on enzymes of crustaceans, fishes and molluscs have been carried out by several authors: trypsinlike enzymes of Eriocheir japonicus ${ }^{1383}$, low molecular weight enzymes in several decapods ${ }^{134)}$ and in Artemia salina ${ }^{135)}$. In the crayfish Astacus leptodactylus midgut gland, four proteazes and three amylases have been observed ${ }^{188)}$. In Crustacea, carbohydrase functions and structure ${ }^{187}$ ) have recently been studied in detail along with several other digestive enzymes ${ }^{180}$.

It is of fundamental importance to know if different marine animals are able to digest components of compounded diets mixed in pellets. It seems that some corn starches are not digested by crustacean carbohydrases ${ }^{188)}$. Adjustment of the $\mathrm{pH}$ of the food to optimal $\mathrm{pH}$ of digestive enzyme activity also has to be known.

In this field, there is a lack of information which must be rectified by biochemists, and by biochemical geneticists, in order that the digestive and metabolic potentials of different populations and their hybrids $^{13 \theta-147)}$, of interest in aquaculture, be measured.

Blood protein characteristics are also of great interest: almost all the transport communication between organs occurs at the level of these carrier proteins, especially those connected with reproduction.

Growth of the ovary depends on the accumulation, in the sexual cells, of various lipids which are metabolized by the ovocytes and constitute vitellus, the future main reserve of the embryos and first larvae. As lipids are hydrophobic, their transport necessitates association with a hydrophilic protein or glycoprotein which constitutes lipoproteins.

For several years it has been known that blood protein contains more lipoproteins in females than in males. This has been shown in several species, such as the crabs Paratelphusa hydrodromus ${ }^{148,149)}$ Carcinus maenas ${ }^{160.181)}$ and the lobster Homarus americanus $^{1 \mathrm{s2})}$.

One of the major results obtained during these last years in physiology of Crustacea, and to a lesser extent in fishes, was evidence of particular lipoproteins linked with vitellogenesis-the vitellogenins.

Recently, the site of the synthesis of these particular lipoprotein has been identified in a subepidermic fat body or adipose tissue of an amphipod Orchestia gammarel la $^{133)}$, and in the fat body and hepatopancreas of an isopod Porcellio dilatatus $^{154)}$. Synthesis of these molecules has also been described in another isopod ${ }^{155,158)}$. At present, vitellogenin synthesis does not seem to occur in hepatopancreas.

The lipoproteins carry different classes of lipids and at present, it is difficult to know exactly which lipoprotein is strictly implicated in vitellogenesis. Twelve lipoprotein may exist in the hemolymph of the shrimp Palaemon serratus ${ }^{167}$; some of them are certainly linked with ovary growth and are true vitellogenins.

In hemolymph of Penaeus japonicus, lipids were associared with high density lipoprotein $\left(\mathrm{HDL}_{1}\right.$ and $\mathrm{HDL}_{2}$ ) and very high density lipoprotein (VHDL) but not with low density lipoproteins, chylomicrons and very low density lipoproteins ${ }^{158)}$. The major lipid classes linked with $\mathrm{HDL}_{2}, \mathrm{HDL}_{3}$ and VHDL are polar lipids. Properties of crustacean hemolymph lipoproteins very probably differ from those of mammalian serum lipoproteins ${ }^{158)}$. A common lipoprotein classification system is needed to clarify research and help further progress. In rainbow trout ${ }^{180)}$, female specific serum protein has been described and compared with egg yolk proteins. It is difficult to correlate the protein of fishes with mammalian blood proteins ${ }^{101)}$. Future studies on blood protein will establish the appropriate characteristics of each lipoprotein composition, and their exact biological role. Mecanisms of endocytosis, pinocytosis and micropinocytosis have recently been recognized as a very important but complex process in cell life ${ }^{102)}$.

The quality of the vitellus contained in the ovocyte and in the eggs, depends on the exact composition of these vitellogenins. It is absolutely necessary to know this composition and its variability and to establish appropriate comparison 
with the composition of the lipovitellins. The quality of the eggs and the survival rate of the larvae greatly depend on these characteristics.

Carotenoid-protein complexes are widely distributed throughout the invertebrates, especially in aquatic forms. There are carotenoproteins in which the carotenoid is associated with lipoglycoprotein $^{183-186)}$, and those where it is bound stoichiometrically to a simple protein or glycoprotein ${ }^{188-189)}$. Further studies are necessary to understand the mecanisms directing the external pigmentation of cultured animals, which increases their commercial value, in crustaceans, fishes and molluscs, and to know the structure of related proteins such as vitamine $A$ binding proteins and visual pigments.

\section{Biochemical Cycles}

Enzymatic activities are regulated by internal cycles such as circadian cycles, molting cycles, and by systematic, scheduled and stereotyped variations at different ages of their life. These variations exist under various environmental factors. Circadian rhythms have mainly been studied until now from the point of view of the behaviour of fish and crustacean, or of the differences in coloration of crustacean chromatophores $^{170)}$. Circadian rhythms of proteases and amylases have been described in Penaeus kerathurus ${ }^{171)}$ and a cyclic variation also exists during the molting cycle in Palaemon serratus ${ }^{172)}$. In the crayfish Orconectes limosus, circadian variations of blood glucose ${ }^{173}$ ) have been described. Waxes of fishes and crustaceans have been studied in natural conditions ${ }^{174)}$ and, in connexion with their behaviour, in copepods ${ }^{175)}$.

In Decapod crustaceans, the results of several authors ${ }^{137,187)}$ show that there is a circadian cycle of enzymatic activities, and two maximal values each day, one in the morning, and the other in the evening, with a twelve hours separation between the two.

These rhythms do not exhibit the same characteristics during the different seasons ${ }^{176)}$. The first peak of digestive enzymatic activities occurs five hours after sunrise, and the second peak twelve hours later.

In aquaculture, it seems more efficient to change the feeding hours, at different months of the year, to adjust the food given to the optimal physiology of the animals cultured at these times where their digestive capacities are greatest.
Enzymatic activities of phosphoamidases, LDH, GLDH, alkaline phosphatase, $\alpha$-n-acetylglucosaminidase, and esterase of Palaemon squilla also exhibit a bicircadian pattern ${ }^{177)}$. Free fatty acids in abdominal muscle of Palaemon serratus maintained on a L-D: 19-5 photoperiod, show two diurnal maximums and one nocturnal one at the end of the dark period. The principal maximum is diurnal, and occurs 7 hours after the beginning of the light phase ${ }^{178}$.

More unexpected are the important quantitative and qualitative variations of carotenoid pigments in different organs of the shrimp Penaeus japonicus at different hours of the day ${ }^{179}$. Three maximums occur at $04.30,10.30$ and $16.30 \mathrm{~h}$ in hepatopancreas and only one maximum is visible at $07.30 \mathrm{~h}$ in the eye-eyestalk complex. Different individual carotenoids show important variations at different hours, suggesting rapid biosynthesis and interconversions during 24 hours.

One may consider almost all the previous precise data-including ours-obtained by the specialists in pigments with a certain skepticism. A better expression of the results would be the maximal and minimal values of each component and their variations at different hours of the day.

It is likely that a given component added in a compounded diet does not have the same efficiency at different hours of the day:" Essential amino acids show circadian variations which are proportionally more important in the case of essential amino acids than in the case of non-essential ones $^{180)}$. Total concentration of amino acids shows two diurnal peaks, at times which are dependent on environmental factors. In experimental winter conditions, these peaks occur earlier $(06.00$ and $18.00 \mathrm{~h})$ than in summer conditions $(09.00$ and $21.00 \mathrm{~h})$. These 12-12 rhythms may be related to the circadian variation of digestive and metabolic enzyme activities.

The general nitrogen metabolism shows large variations during the molting cycle of the crustaceans. In abdominal muscle, total free amino acids increased prior to the molting process up to a maximum at stage $D_{3-4}$, while the large fall just after the molt is due to non-essential amino acids, and mainly to those amino acids known to be involved in osmoregulation. Essential amino acids vary quite differently ${ }^{181}$.

In low vertebrate and invertebrate groups where the physiology is much less regulated than in mammals characterized by very strong homeostatic controls, the normal and natural physiological 
variability have to be measured accurately to gain preliminary knowledge for improving research in aquaculture.

During larval growth, different digestive enzymatic activities vary. Empirical observations in aquaculture tanks and systematic feeding trials led to the conclusion that marine larvae usually begin to eat phytoplankton and later zooplankton.

In Palaemon serratus ${ }^{182}$ ) larvae proteases and amylases do not have the same activities at each larval stage. These crustacean larvae begin as the phytophageous: amylase activity rapidly reaches a high level during zoea $\mathrm{I}$, whereas the increase in protease activity only occurs between the fourth and fifth larval stage. They become more carnivorous, with a high protease activity. Ratio between amylases and proteases shows noticeable variations during the larval growth ${ }^{183)}$.

Similar results have been obtained during the larval development of Penaeus japonicus ${ }^{184)}$ showing a fair increase of the proteasic activities at the end of zoea stage and the beginning of mysis.

During the larval growth of the sea bass Dicentrarchus labrax, all enzymatic activities are very weak at hatching. Trypsin, $\alpha$-glucosidase and alkaline phosphatase increase between 0 and 5 days, then decrease slowly and are quite stable from 15 to 30 days, although other enzymatic activities increase steadily from 0 to 20 days ${ }^{185)}$.

Similar observations have been carried out in the stomach, digestive caeca and gut of young grey mullet Mugil capito ${ }^{1863}$ in correlation with LDH, G6PDH, and oxygen consumption of Salmo irideus eggs ${ }^{187)}$ or in LDH activity during development of shrimp Palaemon serratus ${ }^{188}$.

These data may be used to identify with precision at what larval stage the quality of the food given has to be changed in the rearing tank.

Total free amino acid concentration in shrimp eggs is fourfold higher at hatching than at laying, due to the increase of some amino acids such as proline, glycine, alanine and glutamic acid, whereas the so-called essential amino acids decrease in percentage-chiefly the tryptophane ratio ${ }^{188}$.

Effects of free amino acids in the hatching process are highly probable, although not yet demonstrated. The quality of the reserves, principally lipovitellin, is certainly a key to the success of egg development. The survival rate of the larvae depend on the quality of the eggs i.e. on quality of the reserves, biochemical composition of the vitellin, and biochemical events occurring in the eggs.
Sequences of the apparition of digestive enzymes in the eggs are very well programmed, and constitute the key control of the best use of lipovitellins of egg reserves ${ }^{120}$. Biochemical changes are a more relevant indicator of growth during larval development than either size increase or molt frequency, when assessing the value of various natural or experimental diets ${ }^{101}$. Measurements of quantitative variations of carbon, nitrogen and hydrogen content during growth ${ }^{182)}$ provide a guideline for adjusting food quality to the natural variation of the chemical composition of the reared species. The same adjustment seems to be possible in crustaceans, to control the molting cycle length, and growth, by changing the quality of the food, adapting it to variations of digestive enzymatic activities during the molting cycle ${ }^{183}$.

In aquaculture, growth rate should be measured during the normal growth sequence. Thus it is not necessary to wait several weeks or even several months for the end of the experiments.

Several authors ${ }^{194-197)}$ have shown that relationship between nucleic acids and other cell constituents can be used as indicators of recent growth in marine animals.

In developing shrimp Crangon crangon, changes in DNA and RNA content were used as a measure of increase in cell size, increase in cell number and protein synthesis activity ${ }^{108}$; the growth of the crab Rhithropanopeaeus harrisii was estimated in biochemical terms ${ }^{198}$ ) in order to find appropriate correlation between these factors.

Such a methodology has been used during larval and postlarval development of the shrimp Penaeus japonicus ${ }^{184}$. Cell multiplication assayed by tracing the evolution of the amount of DNA, was high during nauplius stages. RNA concentration rises considerably during zoea stage. During nauplius and mysis, cellular hyperplasy may take place, while cellular hypertrophy would characterize zoea stage. Similar approach has been carried out during the growth of the shrimp Palaemon serratus at different steps of larval growth ${ }^{183)}$.

Discontinuities have been evidenced at the end of zoea stages and with the appearance of the secondary sex characters, on dry weight, total nucleic acid and protein values related to dry weight. DNA and RNA both decrease, the former to a more pronounced extent. The RNA/DNA ratio is a valuable indicator of cell activity. Comparison of total amylase and protease activity with dry weight revealed the same discontinuities on the 
total nucleic acid and protein values.

The use of DNA and RNA measurement could also be of assistance for aquaculture nutritional studies. Best growth rates not only correspond to highest protein content of animals reared, but also to highest RNA and DNA content per animal. An inadequate diet decreases protein, DNA and RNA content, as has been shown in young lobsters Homarus gammarus. ${ }^{200}$ )

\section{Ecobiochemistry}

As for ecophysiology, biochemical characteristics are directly or indirectly influenced by environmental factors. Normal biochemical cycles seen in the preceding chapters are modified by variations of temperature, salinity photophase, intensity and wavelength of light. In nature, these factors are not the same in winter and summer conditions ${ }^{88,187,180,201)}$.

Studies of short term and long term adaptation of enzymatic activities to variation of environmental factors, under the direct influence of these factors, or under the effect of metabolites or hormones may be called ecobiochemistry, in parallel to ecophysiology. In this field, there is some overlapding with classical biochemistry, physiology and ecology, but the domain itself has not been greatly studied, excepting some remarkable works and publications ${ }^{202-213)}$.

Marine crustaceans employ the same major pathways to synthesize phospholipids in vertebrates $^{214}$. In gill mitochondria of goldfish, total phospholipids remain unchanged when adapted from $10^{\circ}$ to $30^{\circ} \mathrm{C}^{218}$. In the carp, the ratio of phospholipid to protein in liver mitochondrial membranes does not differ at cold and warm acclimation temperature ${ }^{218)}$.

In the shrimp Palaemon serratus, total lipid level and polyunsaturated fatty acids show an inverse relationship with temperature ${ }^{217}$. The different phospholipids extracted from the gill mitochondria of the crab Carcinus maenas show that phosphatidylethanolamine increases and phosphatidylcholine decreases in animals living at low temperatures $^{\text {(b). }}$.

In fishes, acclimation to different temperatures modifies thyroid physiology $y^{218}$. Rainbow trout acclimated for 3 weeks at $9^{\circ} \mathrm{C}$ and $21^{\circ} \mathrm{C}$ during winter have an identical fibrinogen level. Experiments conducted during spring show that fibrinogen is notably lower at $21^{\circ} \mathrm{C}$ than at $9^{\circ} \mathrm{C}^{219)}$. In Salmo gairdneri and Tinca tinca, GOT and GPT transaminases are the most sensitive enzymes after rapid thermal variations; amylase varies if thermal variations are moderate; alkaline phosphatase and malate dehydrogenase varies if thermal variation is significant ${ }^{220)}$. Generally, one enzymatic activity is the result of several isoenzymes, each one having a different pattern of activity at different temperatures. Acclimation for six weeks at different temperatures ranging from $14^{\circ}$ to $30^{\circ} \mathrm{C}$ leads to isoenzymatic patterns often very different from one temperature to the other ${ }^{221)}$.

- Salinity is also a very important factor acting at the biochemical level, on the physiology of aquatic animals ${ }^{222,228)}$, and on their growth, for instance in postlarval peneid shrimps ${ }^{24)}$. In the gills of Anguilla anguilla $\left(\mathrm{Na}^{+}+\mathrm{K}^{+}\right)$-dependent adenosine triphosphatases show a specific activity lower at $18^{\circ}$ in sea water than at $5^{\circ}$ and $10^{\circ} \mathrm{C}$; under these conditions, there is a decrease in the amount of enzyme. Enzymes from freshwater-adapted animals acclimatized to $5^{\circ}$ and $10^{\circ} \mathrm{C}$ had lower specific activities than those acclimatized to $18^{\circ} \mathrm{C}$ and this decrease was not due to a decreased amount of enzymes $^{225)}$. There is a lipid dependence of the activity temperature relationship of $\left(\mathrm{Na}^{+}+\mathrm{K}^{+}\right)$activated ATP ases ${ }^{22 \theta)}$. The activity of Glucose-6Phosphate dehydrogenase is influenced by salinity in the red sea bream ${ }^{2277}$, as well as blood parameters in Tilapia zilli ${ }^{228}$. Future works on enzymes controlling lipid metabolism are necessary to gain further knowledge of muscle growth, gill efficiency and liver physiology ${ }^{228,230)}$.

Light is an ecological factor which has not been greatly studied despite its importance. Circadian rhythms of digestive enzymatic activities show less variations when animals are maintained in darkness They reappear after a short and weak exposure to light ${ }^{18 \eta}$. Wavelengths stimulating the digestive enzymatic activities in Palaemon serratus most intensively are very close to $360,540 \mathrm{~nm}$ and a weaker effect is obtained for $620 \mathrm{~nm}^{231)}$. Green light and a $16 \mathrm{~h}$ photoperiod generally give a good response as concerns digestive enzyme secretion in crustacea. These enzymatic activities does not have the same values at different seasons. In the sea bass Dicentrarchus labrax, the best growth has been observed at $18 \mathrm{~h}$ photoperiod; the larvae die if light intensity is too high.

At the enzymatic level, different isoenzymatic patterns have been observed in the shrimp Palaemon serratus when the animals are maintained during five weeks under different illuminations, ranging from 75 to $1,200 \mathrm{~lx}^{298}$. 
The chemical composition of the food components ingested and assimilated greatly influences the composition of the animals themselves, and the function of their constituents. A semiquantitative approach can be used with histoenzymology and blood parameter variations in different nutritional conditions. Thus, in mussel Mytilus californianus, digestive epithelium observations, and plasma carbohydrate, lipid and protein content have been adopted ${ }^{234)}$. The effects of dietary composition on pancreatic activities have been studied in mammals ${ }^{235-287)}$.

Very few works have dealt with the influence of the qualitative composition of the food on the enzymatic activities of marine species, such as Mytilus edulis ${ }^{288}$, Seriola quinqueradiata ${ }^{230)}$ or carp $^{240)}$. The effects of the carbohydrate and protein composition of compound diets on growth rate and on the amylase and protease content of the hepatopancreas have been studied in Palaemon serratu $^{240)}$. Maximal specific protease activity is reached when the food protein level is $45 \%$, and maximal amylase activity is reached when carbohydrate amounts to $2.8 \%$. When the food carbohydrate and protein are higher or lower, the values of specific enzymatic protein diminish ${ }^{241}$. The use of biochemical methodology to establish the exact proportion of diet constituents does not immediatly give the most appropriate food composition for each species. But it represents an efficient help in trying to systematically define the nutritional needs of cultured species- and their variations during growth ${ }^{182)}$ or in different environmental conditions ${ }^{137,231)}$. Consequently, it may be assumed that a more or less specific food has to be given to animals growing under specific conditions.

In natural environment, reproduction occurs not only when an appropriate food is available but also for certain temperature ranges, light intensity and photoperiod. Controlled conditions may simulate such environmental variations. Peneid shrimp grow their ovaries and spawn in any sea$\operatorname{son}^{242}$, when vitellogenin is produced and used for reproductive aims instead of for somatic and physiological purposes.

The cost of reproduction that each individual has to pay so that the following generation may exist and the species survive, may be measured not only in physiological terms ${ }^{243}$, but also in biochemical and energetical ones. The site and the biochemical mechanisms for synthesis of vitellogenins have not as yet been clarified despite recent progress ${ }^{158-157)}$, but production of reproductive reserves is situated under the endocrinological processes.

Conditions in which animals have been reared in aquaculture have a noticeable influence on their biochemical characteristics, and consequently, not only on their taste, but also on their conservation.

It seems possible to enhance the taste of animals ${ }^{244-248}$ reared in aquaculture by adjusting the salinity of the tanks before selling, by using characteristic flavoured compounded diets, or by adjusting the composition of diets to orient the physiology to specific metabolic pathways, particularly to different lipid class synthesis.

A similar method may be used to enhance the pigmentation of fishes and crustacea, by giving them food enriched with carotenoids, during an appropriate time. Such a method is already in practice in commercial tricolor carp culture in Japan, using compounded diets containing Spirulina.

\section{Endocrinology}

Metabolism, physiology and biochemistry of marine animals are directly or indirectly regulated by hormones ${ }^{247}$ ). Respiration ${ }^{248}$, muscle and hepatopancreas LDH activity ${ }^{248}$ among other functions are under endocrine control. In the shrimp Palaemon serratus, extirpation of MEX, Bellonci's organ and sinus gland induced a fall in digestive enzymatic activity like that observed in eyestalkless shrimps. Eyestalk removal or extirpation of Bellonci's organ does not reduce the amplitude of digestive enzymatic rhythms. Responses to extirpation varies with seasons ${ }^{200}$. Eyestalk of crustacean are complex, with different kinds of neurosecretory cells ${ }^{251-254)}$, they contain from three to seven types of secretory granules ${ }^{256}$ showing a circadian neurosecretory activity ${ }^{2083}$. Knowledge of relationships between neurosecretions ${ }^{257)}$, chromatine of target tissue cells ${ }^{258}$ and histone composition ${ }^{256}$ is actually increasing. Crustacean hyperglycemic hormones $(\mathrm{CHH})$ have been localized in the $\mathrm{X}$ organ sinus gland complex ${ }^{2(0)}$ which is also responsible for producing at least six different hormonally active substances ${ }^{261)}$. Eyestalk ablation produces serious effects on the synthesis of digestive enzymes ${ }^{197,287)}$, the female reproduction, especially in Peneids ${ }^{282,283)}$, and the nitrogen metabolism $^{264,208)}$.

The use of natural hormones, some of them 
identified as peptides, or synthetic ones or their analogs, has opened up a wide area of research and application for strict control of aquaculture.

A similar application of hormones to economic fishes and in fish aquaculture has been developed after different investigations ${ }^{267-274)}$. Their use in controlling reproduction is beginning to develop well. In molluscs, there is much less knowledge of different hormones and their role in the physiology and biochemistry of different species.

\section{Ecophysioparasitology}

The parasites which eventually live and develop inside the organisms are in the same situation as the cells of the organs. In order to survive and develop, they must adapt to the composition of the internal medium, to the extent that the characteristics and variations of this latter correspond to their physiological needs.

In the state of good physiological health, the reaction capacities of heathly organisms are sufficient to stop-in most cases-the intrusion of parasites liable to attack them. Often, modifications of the external medium, either climatic or anthropogenic, render the organisms weaker, and reduce their defense mechanisms. The conditions of the medium which render defense capacities maximal should therefore be well known in order to realize optimal preventive condition in aquaculture.

The presence of the parasite modifies the composition of the internal medium and even, directly or indirectly, the intracellular reaction characteristics of the cells of various organis in its host.

Studies on metabolic activity in relation to parasitism have been neglected although they are especially important in euryhaline species, which must regulate their internal medium and their metabolism according to the salinity of the environment. The influence of the parasites may directly affect the structure of the cells and the tissues themselves, or, indirectly, the hormonal equilibrium, the water content of the host, or the concentration of mineral and organic elements of the hemolymph.

Studies have been conducted on the parasitic effects of: Sacculina on hemolymph protein concentrations in Portunid crabs $^{278}$ ) and Aerococcus viridans (var.) homari on glycogen and ATP in Homarus americanus ${ }^{278)}$, on glucose, total carbohydrate and lactic acid in the same crustacean ${ }^{277}$. The consequences of Gaffkemia are affected by a reduction of sea water salinity ${ }^{278)}$. Hemolymph proteins and several enzymatic activities such as esterases, chymotrypsin acidic and alkaline phosphatases and $\alpha$-glucosidases in the crab Carcinus maenas are modified by the presence of the muscular microsporidia Thelohania maenadi ${ }^{278)}$. Hemolymph total protein and glucose levels of the crab Carcinus mediterraneus are reduced significantly when they are parasitized by this microsporidia ${ }^{280}$.

The survival capacities of the parasite when the parasited hosts are subjected to considerable variations of the external medium should be ascertained. A very good knowledge of the physiology of the parasites, the relations between the biochemistry of the host and that of the parasites, and their physiological and ecophysiological limits in aquaculture is required in order to treat the infected animals by carefully modifying the physical and chemical conditions of the external medium. Chemical treatments and antiparasitic compounds may be associated with these modifications if required. This group of investigations constitutes what may be designated ecophysioparasitology. Experimentation in this field is needed to avoid serious disease problems in aquaculture ${ }^{2811}$.

Experimental variations in the environmental water temperature and salinity affect protein level and the metabolic indicators of carbohydrate metabolism. Proteinemia varies, with temperature and salinity, but parasitic infection accentuates these variations.

The influence of the combined factors of salinity and temperature was studied in conditions comparable to those pertaining in winter and summer in natural habita ${ }^{288}$.

Parasites may adapt their physiology and even their biochemistry to those of the host. In this respect, free amino acids of microsporidia were generally found to be in inverse proportion to the level in the host $\mathrm{t}^{294,2987}$. The amino acids which are found to exist at high levels in the parasites correspond to essential amino acids of the Crustacea. This direct complementarity represents a parasitism reaching the biochemical level. It is likely that parasites do not develop metabolic pathways corresponding to the molecules present in relatively high concentration in the internal medium of the host. These results show that there is a gap in our knowledge namely the complementarity between the metabolic cycles of the host and those of the parasites. Such a subject has been much neglected, especially in marine parasitology.

Similar considerations concerning the appari- 
tion of various diseases under the effect of variations of environmental factors, or under external stresses, may also lead one to consider the ecophysiopathology concept.

\section{Conclusion}

Techniques are today increasingly being borrowed from physiology and biochemistry to solve numerous problems arising not only in aquaculture, but also in marine biology and biological oceanography ${ }^{288}$.

New areas of research need greater efforts to increase our knowledge on essential amino acids ${ }^{287}$ ) control of chemical composition and size of living preys ${ }^{288,288)}$, physiological characteristics of larval stages, optimal effects of environmental factors on survival, growth and reproduction, feeding stimulants enhancing food consumption ${ }^{200}$ biochemical composition of cultivated species and their parasites ${ }^{201)}$, enzyme characteristics, biochemical cycles $^{282)}$, lipovitellins, vitellogenins, prediction of growth by RNA and DNA measurements, adaptation of enzymes to food composition, role of hormones in marine species ${ }^{293}$, biochemical adaptation between hosts and parasites.

The methods to be adopted must take into account the different organizational levels of living matter. It seems no longer possible to develop research in aquaculture in only one field of the biological sciences; interdisciplinary research is useful, and it is gradually becoming a necessity in each country concerned by aquaculture production. Comparison of results obtained in different geographical areas will promote international cooperation.

\section{References}

1) A. Kanazawa, M. Shimaya, M. Kawasaki, and K. Kashiwada; Bull. Japan. Soc. Sci. Fish, 36, 949-954 (1970)

2) O. Deshimaru and K. Shigheno: Aquaculture, 1, 115-133 (1972).

3) O. Deshimaru and K. Kuroki: Bull. Japan. Soc. Sci. Fish. 40, 413-419 (1974).

4) C. B. Subrahmanyam and C. H. Oppenheimer: Proc. World Maric. Soc., 1, 91-100 (1970).

5) A. Pastoureaud: Contribution à l'étude de l'alimentation de Penaeus kerathurus Crustacé Décapode. Thèse 3ème cycle. Océan. Biol., Univ. Aix Marseille (1972) 56 p.

6) J. W. ANDrews, L. V. Sick, and G.J. Baptist: Aquaculture, 1, 341-347 (1972).

7) K. L. Shewbart, W. L. Mies, and P. D. Lunwig: US. Dept. Comm. Rep. No COM-73-11794.
NOAA, Office Sea Grant, Rockville, Md (1973) $52 \mathrm{p}$.

8) M. B. NEw: Aquaculture, 21, 101-128 (1980).

9) A. Kanazawa, S. Teshima, S. Matsumoto, and T. Nomra: Bull, Japan. Soc. Sci. Fish., 47, 13711374 (1981).

10) J. R. M. Forster and T, W. Beard: Cons. Intern. Explor. Mer, CM 19 9/E, 6 (1969) 6 p.

11) G. Cuzon: Elevage et alimentation artificielle de Crangon crangon, Palaemon serratus et Penaeus kerathurus. Thèse 3ème cycle. Océan. Biol. Univ. Aix-Marseille (1970) 107 p.

12) J. Patrois: Contribution à l'étude du comportement de l'alimentation et du métabolisme lipidique de Palaemon serratus. Thèse 3ème cycle, Océan. Biol. Univ. Aix-Marseille (1974) 65 p.

13) A. Campillo and P. Luquet: Rec. Trav. Inst. Péches Marit., 39, 407-414 (1975).

14) G. Cuzon, H. J. Ceccaldi, and D. Cognie: Tethys, 6, 799-804 (1974).

15) M. Regnault and P. Luquet: Ann. Nutr.Aliment., 28, 523-537 (1974).

16) M. Regnault: Etude de la croissance chez les crevettes Crangon crangon, d'après les variations quantitatives de ses acides nucléiques; influence de l'alimentation. Thèse Doct. Sc., Univ. Paris VI (1972) $183 \mathrm{p}$.

17) M. Regnault: Oceanis, 41, 73-81 (1978).

18) D. I. ZANDEE: Archs. Internat. Physiol. Biol., 74, 35-44 (1966).

19) C. B. Cowey, J. Adron, and A. Bl.AIR: $J$. Mar. Biol. Ass. U. K., 50, 87-95 (1970).

20) C. B. COWEy and J. R. M. Forster: Mar. Biol., 10, 77-81 (1971).

21) K. L. Shewbart, W. L. Mies, and P. D. Ludwig: Mar. Biol., 16, 64-67 (1972).

22) L. S. Mryajima, G. A. Broderick, and F. D. ReIMer: Proc. World Maric. Soc., 6, 699-704 (1975).

23) W. A. Allen and J. Krlgure: Comp. Biochem. Physiol., 50 A, 771-775 (1975).

24) A. Kanazawa and T. Teshima: Bull. Japan. Soc. Sci. Fish., 47, 1371-1374 (1981).

25) H. J. Ceccaldi: Publi. FAO-CGPM, AG/72/808/01/72 (1972) $9 \mathrm{p}$.

26) H. J. Ceccaldi: Oceanis, 4, 55-62 (1978).

27) Z. P. ZEIN-ELdIN and J. CoRliss: Proc. FAO Techn. Conf. on Aquaculture, FIR: AQ/Conf. 76/ E33 (1976) $10 \mathrm{p}$.

28) Z. P. ZeIn-Eldin and S. P. Meyers: Proc. World Maric. Soc., 4, 299-317 (1973).

29) M. B. New: Aquaculture, 9, 101-144 (1976).

30) M. B. NEw: Proc. World Maric. Soc., 7, 277287 (1976).

31) B. J. Martin: Tethys, 9, 261-265 (1980).

32) H. Aoe, I. Masuda, I. Abe, T. SAito, T. Toyoda, and S. Kitamura: Bull. Japan. Soc. Sci. Fish., 36, 407-413 (1970). 
33) T. Murai, T. Akiyama, and T. Nose: Bull. Japan. Soc. Sci. Fish., 47, 523-527 (1981).

34) S. Konosu, S. Katori, T. AkiYama, and T. Mori: Bull. Japan. Soc. Sci. Fish., 24, 300-304.

35) J. Kittaka: Proc. First Int. Cong. Aquaculture Nutr. Delaware (Sea Grant), 249-285 (1976).

36) J. R. M. Forster and P. A. GABbott: J. Mar. Biol. Assoc. U. K., 51, 943-961 (1971).

37) K. Krtabayashi, K. Shudo, K. Nakamura, and S. IsHIKAWA: Bull. Tokai Reg. Fish. Res. Lab., 65, 109-118 (1971).

38) O. Deshimaru and Y. YONE: Bull. Japan. Soc. Sci. Fish., 44, 1161-1163 (1978).

39) S. H. Abdel-Rahman, A. Kanazawa, and S. Teshima: Bull. Japan. Soc. Sci. Fish., 45, 14911494 (1979).

40) N. Nicolaides and A. N. Woodal: J. Nutr., 78, 431-437 (1962).

41) J. D. Castell, R. O. Sinnhuber, J. H. Wales, and D. J. LEE: J. Nutr., 102, 77-86 (1972),

42) J. D. Castell, R. O. Sinnhuber, P. J. Lee, and J. H. WALES:-J. Nutr., 102, 87-92 (1972).

43) J. D. Castell, D. J. Lee, and R. O. Sinnhuber. J. Nutr., 102, 93-100 (1972).

44) D. J. Lee, L. N. RoeHM, T. C. UU, and R. O. SINNHUBER, : $\quad J$. Nutr., 92, 93-98 (1967).

45) T. Watanabe, F. Takashima, and C. Ogino: Bull. Japan. Soc. Sci. Fish., 40, 181-188 (1974).

46) T. Watanabe, I. Kobayashi, O. Utse, and C. OGINo: Bull. Japan. Soc. Sci. Fish., 40, 387392 (1974).

47) T. Watanabe, C. Ogino, Y. Koshimshi, and T. Matsunaga: Bull. Japan. Soc. Sci. Fish, 40, 493-499 (1974).

48) T. C. Yu and R. O. Sinnhuber: Lipids, 7, 450454 (1972).

49) T. C. YU and R. O. SinnhuBer: Lipids, 10, 63-66 (1975).

50) T. Watanabe, O. Utsue, I. Kobayashi, and C. OgINo: Bull. Japan. Soc. Sci. Fish., 41, 257262 (1975).

51) T. Watanabe, T. Takeuchi, and C. Ogino: Bull. Japan. Soc. Sci. Fish., 41, 263-269 (1975).

52) Y. YONe and M. FuJII: Bull. Japan. Soc. Sci. Fish., 41, 73-77 (1975).

53) Y. Yone and M. FuנrI: Bull. Japan. Soc. Sci. Fish., 41, 79-86 (1975).

54) M. FuJI and Y. Yone: Bull. Japan. Soc. Sci. Fish., 42, 583-588 (1976).

55) C. B. Cowey, J. M. OWen, J. W. Adron, and C. MiddLeton: Brit. J. Nutr., 36, 479-486 (1976).

56) J.-C. Guary, M. Kayama, Y. Murakami and H. J. Ceccaldi: Aquaculture, 7, 245-254 (1976).

57) A. Kanazawa, S. Teshima, S. Tokiwa, and H. J. Ceccaldi: Oceanol. Acta. 2, $41-47$ (1979).

58) M. Kayama, Mi. Hirata, A. Kanazawa, S. TOKIWA, and M. SAIto: Bull. Japan. Soc, Sci. Fish., 46, 483-488 (1980).

59) A. Kanazawa, S. Teshima, S. Tokiwa, M. Endo, and F. A. AbD-El-Razek: Bull. Japan. Soc. Sci. Fish., 45, 961-975 (1979).

60) P. A. SANDIFER and J. D. JOSEPH: Aquaculture, 8, 129-138 (1976).

61) T. Watanabe, F. Oowa, C. Kitajima, and S. Fujrta: Bull. Japan. Soc. Sci. Fish., 46, 35-41 (1980).

62) C. Kitajima, T. Arakawa, F. Oowa, S. Fujita, O. IMADA, T. WATANABE, and Y. Yone: Bull. Japan. Soc. Sci. Fish., 46, 43-46 (1980).

63) C. Kitajima, M. Yoshida, and T. Watanabe: Bull. Japan. Soc. Sci. Fish., 46, 47-50 (1980).

64) K. Yamada, K. Kobayashi, and Y. Yone: Bull. Japan. Soc. Sci. Fish., 46, 1231-1233 (1980).

65) S. Chapelle, G. Brichon, and G. Zwingelstein: Biochem. Syst. Ecol., 9, 333-338 (1981).

66) D. E. Conklin, L. R. d'Abramo, C. E. Bordner, and N. A. BAUM: Aquaculture, 21, 243-249 (1980).

67) S. Teshima and A. KanazAwa: Bull. Japan. Soc. Sci. Fish., 37, 63-67 (1971).

68) D. R. IDLER and P. Wiseman: Internat. J. Biochem., 2, 91-98 (1971).

69) S. Teshima: Bull. Japan. Soc. Sci. Fish., 37, 671-674 (1971).

70) S. Teshima and A. Kanazawa: Bull. Japan. Soc. Sci. Fish., 38, 1305-1310 (1972).

71) J.-C. Guary and A. Kanazawa: Comp. Biochem., Physiol., 46 A, 5-10 (1973).

72) S. Teshima and A. Kanazawa: Mem. Fac. Fish. Kagoshima Univ., 22, 15-19 (1973).

73) A. Kanazawa, J.-C. Guary, and H. J. Ceccaldr: Comp. Biochem. Physiol., 54 B, 205-208 (1976).

74) A. Kanazawa, N. Tanaka, S. Teshima, and K. Kashiwada: Bull. Japan. Soc. Sci. Fish., 37, 211-215 (1971).

75) G. K. KUlKarni and P. K. Joshr: Hydrobiologia, 75, 27-32 (1980).

76) E. N. KING: Comp. Biochem. Physiol., 15, 93102 (1965).

77) C. Mangum and W. Van Winkle: Amer, Zool,, 13, 529-541 (1973).

78) W. C. HulberT, D. E. Schnemer, and T. W. Moon: Marine Biology, 36, 223-231 (1976).

79) C. Mangum and A. L. Weiland: J. Exp. Zool., 193, 257-264 (1975).

80) M. Regnault: J. Comp. Physiol., 133, 199-204 (1979).

81) D. H. SpaArgaren: Comp. Biochem. Physiol., 45 A., 773-786 (1973).

82) G. Charmantier et J. P. Trilles: Gen. Comp. Endocr., 31, 295-301 (1977).

83) D. H. SpaArgaren: Comp. Biochem. Physiol., 47 A, 499-512 (1974).

84) G. Charmantier: Comp. Biochem, Physiol,, 50 A, 339-345 (1975).

85) G. P. Ennis: J. Mar. Biol. Assoc. U. K., 53, 531598 (1973).

86) D. A. Hugues: Biol. Bull., 136, 398-404 (1969). 
87) B. L. Powell: Proc, Irl. Acad., 64 B, 379-399 (1966).

88) K. R. RAO: Broteria, 37, 3-11 (1968).

89) P. RICHARD: J. exp. mar. Biol. Ecol, 35, 137146 (1978).

90) M. Regnault: Marine Biology, 11: $35-44$ (1971).

91) P. Richard: Ann. Inst. ocêanogr. Paris, 52, 79-87 (1976).

92) E. Spazlani and S. B. Kater: Gen. Comp. Endocr. 20, 534-549 (1973).

93) J. Patrols, H. J. Ceccaldi, T. Ando, A. KanaZAWA, and S. TeshimA: Bull. Japan. Soc. Sci. Fish., 44, 139-141 (1978).

94) A. Kanazawa, J.-C. B. Guary, and H. J. CeCCALDI: Comp. Biochem. Physiol., 54 B, 205-208 (1976).

95) A. Kanazawa, S. Teshima, Y. SaKamoto, and J.-C. Guary: Bull. Japan. Soc. Sci. Fish., 49, 1003-1007 (1976).

$96)$ H. IsHoka: Bull. Japan. Soc. Sci. Fish., 46, 523-531 (1980).

97) B.J. MARTIN and H.J. CeCCAldi: Biochem. Syst. Ecol., 5, 151-154 (1977).

98) J.-C. GuarY, M. Kayama, and Y. MuraKami: Marine Biology, 29, 335-341 (1975).

99) S. Saxamoto, A. Eto, M. Furuich, and Y. YoNe: Bull. Japan. Soc. Sci. Fish, 45, 1179 1183 (1979).

100) G. Duchateau and M. Florkin: Archs. int. Physiol. Bioch., 63, 213-221 (1955).

101) O. KINNE: Helgolander wiss. Meeresunters., 9, 433-458 (1964).

102) R. E. WEBER and W. J. A. MARreWIJ: Netherl J. Sea, Res, m 5, 391-415 (1972).

103) R. E. Werer and D. H. SpaARgaren: Netherl. J. Sea Res., 5, 108-120 (1970).

104) J. Dorgelo: Biol. Rev, 51, 255-290 (1976).

105) P. RichaRd: Biochem. Syst. Ecol., 5, 297-300 (1977).

106) C. S. LeE, F. Hu and R. HrRano: Marine Ecology 4, 169-174 (1981).

107) R. B. LAUGHLIN and J. M. NefF, Narine Ecology 5, 319-332 (1981)

108) G. C. Laurence and W. Huntting Howell: Marine Ecology, 6, 11-18 (1981).

109) M. Kryono and R. Hirano: Rapp., P.-v. Rêuni Cons. int., Explor. Mer., 178, 334-336 (1981).

110) D. Coatanea: Contribution à l'étude du facteur lumière sur la biologie de Penaeus kerathurus et Palaemon serratus. Thèse Doctorat 3ème cycle. Université Aix-Marseille, 74 p. (1974).

111) A. Van Wormhoudt and H. J. Ceccaldi: Colloque Aquaculture, Brest. Actes Coll. CENXO, 1, 101-109 (1974).

112) N. R. Bottino, J. Gennity, M. L. LiLly, E.
SmMONs, and G. FINNE: Aquaculture, 19, 139148 (1980).

113) T. SiNGH: Aquaculture, 20: 251-256 (1980).

114) J. Mc D. MAIR： J. exp. mar. Biol. Ecol., 45, 6982 (1980)

115) M. Florkin, G. Duchateau-Bosson, C. JeunAUX, and E. SChoffenies: Arch. int. Physiol. Biochem., 72, 892-906 (1964).

116) C. Vincent-Marque and R. Gilles: Comp. Biochem. Physiol., 35, 479-485 (1970).

117) D. H. SpaARgaren: Netherl. J. Sea Res., 5, 416-436 (1976).

118) T. Suzuki and M. SuYama: Bull. Japan. Soc. Sci. Fish., 46, 591-597 (1980).

119) A.E. NeEDHAM: Physiologia comp. Oecologia, 4, 209-239 (1957).

120) S. SHImeno, M. TAKeoA, and H. SASAKr: Bull. Japan. Soc. Sci. Fish., 47, 191-195 (1981).

121) L. B. Denne. Comp. Biochem. Physiol, 26, 1730 (1968).

122) F. L. Castille and A. L. Lawrence: Comp. Biochem. Physiol., 70 A, 525-528 (1981).

123) D. F. Alderdice: Marine Ecology, I, 3, 0. Kinne ed.,-Environmental factors, I, 3, 1659 (1972).

124) A. Beis, V. A. Sammit, and E. A. Newsholme: Eur. J. Biochem., 104, 209-215 (1980).

125) E. J. Devillez; Comp. Biochem. Physiol, 14, 577-586 (1965).

126) E. J. De Villez and K. Buschlen: Comp. Biochem. Physiol., 21, 541-546 (1967).

127) B. T. SATHER: Comp. Biochem. Physiol, 28, 371-379 (1969).

128) N. Blandamer and R. B. Beechey: Comp. Biochem. Physiol., 13, 97-105 (1964).

129) R. Zwilling, G. Pflemerer, H. H. Sonneborn, K. Kraft, and I. Stucky: Comp. Biochem. Physiol., 28, 1275-1287 (1969).

130) G. Pfleiderer, R. Zwilling, and H. H. SonNEBORn: Hoppe-Seyler's Z. Physiol. Chem. 348, 1319-1331 (1967).

131) D. Herbold, R. Zwhlling, and G. Pfleiderer: Hoppe-Seyler's Z. Physiol. Chem., 352, 583-592 (1971).

132) B. J.Gates and J. Travis: Biochemistry, 8, 4483-4489 (1969).

133) T. Murumatsu and $T$. Morita: Comp. Biochem. Physiol, 70 B, 527-533 (1981).

134) J. R. Armstrong and E. J. De Villez: Can.J. Zool., 56, 2225-2229 (1978).

135) A. Ollala, C. Ojuna, J. Sebastian, A. Sillero, and M. A. G. Sillero: Biochem. Biophys. Acta, 523, 181-190 (1978).

136) M. Durliat and R. VRanckx: Comp. Biochem. Physiol., 71 B, 155-163 (1982).

137) A. Van WormhoudT: Adaptation des enzymes digestives, de leurs cycles et de leur contrôle aux facteurs du milieu chez Palaemon serratus (Cru- 
stacea, Decapoda). Thèse Doctorat d'Etat, Univ. Aix-Marseille, 351 p. (1980).

138) J. Trellu: Etude de diverses enzymes de Crustacés marins suivant le régime alimentaire, le développement, les chocs thermiques et l'éclairement; application à l'aquaculture et aux rejets thermiques en mer. Thèse Docteur Ingénieur, Univ. Aix-Marseille, 216 p., (1978).

139) N. TANIGUCHI and Y. OKaDA: Bull. Japan. Soc. Sci. Fish., 46, 447-443 (1980).

140) C. J. Sindermann: Proc. Sym . Exp. Mar. Ecol. Occ. Publ. $N^{\circ}$ 2. Grad. Sch. Oceanogr. Rhode Island USA, 33-38 (1964).

141) A. Crosby Longwell and S. S. Stiles: Bull. Amer. Malacol. Union Inc., March 36 (1973).

142) G. B. Johnson: Science, 184, 28-37 (1974).

143) M. L. Tracey, K. Nelson, D. Hedgecock, R. A. Shleser, and M. L. Pressick: J, Fish. Res. Board. Can., 32, 2091-2101 (1975).

144) M. Iwata: Mem. Fac. Fish. Hokkaido Univ., 22, 193-258 (1975).

145) D. Hedgecock, K. Nelson, R. A. Shleser, and M. L. TraceX： J. Heredity, 66, 114-118 (1975).

146) D. Hedgecock, R. A. Shleser, and K. Nelson: J. Fish. Res. Board Can., 33, 1108-1119 (1976).

147) K. Nelson and D. Hedgecock: Amer. Naturalist., 111, 361-365 (1977).

148) R. G. ADrYodi: Indian J. Exptl. Biol., 6, 144147 (1968).

149) R. G. ADIYodi: Indian J. Exptl. Biol., 6, 200203 (1968).

150) H. J. Ceccaldi: C. R. Soc. Biol., 161, 11051110 (1967).

151) H. J. Ceccaldi and J.-L. Martin: C. R. Soc. Biol., 163, 2638-2641 (1969).

152) J. Barlow and G. J. Ridgway: J. Fish. Res. Canada, 26, 2101-2109 (1969).

153) H. Junera and Y. Croisille: C. R. Acad. Sci. Paris D., 290, 703-704 (1980).

154) J.-L. Picaud and C. Souty: C. R. Acad. Sci. Paris D., 290, 123-125 (1980).

155) J.-L. PiCaud and C. Souty: C. R. Acad. Sci. Paris D., 290, 1019-1021 (1980).

156) C. Souty and J.-L. PiCAud: Reprod. Nutr. Develp., 21, 95-101 (1981).

157) H. Nakagawa and H.J. Ceccaldi: Comp. Biochem. Physiol., (in press).

158) S. Teshima and A. Kanazawa: Bull. Japan. Soc. Sci. Fish., 46, 51-55 (1980).

159) S. Teshima and A. Kanazawa: Bull. Japan. Soc. Sci. Fish., 46, 57-62 (1980).

160) A. Hara and H. Hiral: Comp. Biochem. Physiol., 59 B, 339-343 (1978).

161) H. Perrier, J. P. Delcroix, C. Perrier, and J. Gras: Comp. Biochem. Physiol., 49 B, 679-685 (1974).

162) J. L. Goldstein, R. G. W. Anderson, and M. S. Brown: Nature, 279, 679-685 (1979).
163) R. Kuhn and N. A. Sorensen: Ber. dt. Chem. Ges., 71 : 1879-1888 (1978),

164) P. F. ZaGalsky, D. F. Cheesmann, and H. J. Ceccaldi: Comp. Biochem. Physiol., 22, 851871 (1967).

165) W. E. Fyee and J. D. O'Connor: Comp. Biochem. Physiol., 47 B, 851-867 (1974).

166) D. F. Cheesman, P. F. Zagalsky and H. J. CeCCAldi: Proc. Roy. Soc. Lond., B. 164, 130 151 (1966).

167) H. Nakagawa, M. Kayama, and J. Asakawa: J. Fac. Fish. Anim. Husbandry, Hiroshima Univ., 10, 61-71 (1971).

168) H.J. CecCaldi: Recherches sur la biologie des associations entre protéines et caroténoides chez les Crustacés Décapodes: aspects métaboliques et moléculaires. Thèse Doct. D'Etat. Univ. Aix-Marseille, 479-p. (1968).

169) P. F. ZaGalsky: Comp. Biochem. Physiol., 71 B, 243-247 (1982).

170) C. Pasteur-Humbert: Soc. Sci. nat. phys. Maroc, 42, 127-144 (1962).

171) A. Van WormhoudT, H. J. Ceccaldi, and Y. le Gal: G. R. Acad. Sci. Paris, D, 274, 1208 1211 (1972).

172) A. Van Wormhoudt, Y. Le Gal, and H.J. Ceccaldi: C. R. Acad. Sci. Paris D, 274, 13371340 (1972).

173) A. Hamann: J. Comp. Physiol, 89, 197-214 (1974).

174) M. Kayama and J. C. Nevenzel: Marine biology, 24, 279-283 (1974).

175) T.S. PETIPA: Dokl. Akad. Nauk. SSSR, 156, 361-363 (1964).

176) A. Van Wormhoudt: Biochem. System. Ecol., 5, 301-307 (1977).

177) J. Trellu and H. J. Ceccaldi: J. interdiscipl. Cycle Res., 8, 357-359 (1977).

178) B. J. Martin and H. J. Ceccaldi: C. R. Soc. Biol., 171, 608-612 (1977).

179) M. Otazu-Abrill and H. J. Ceccaldi: $\quad C . R$. Soc. Biol., 172, 684-690 (1978).

180) P. Richard, A. Van Wormhoudt, and H.J. CECCALDI: Biochem. Syst. Ecol., 7, 65-67 (1979)

181) P. Richard: Comp. Biochem. Physiol, 67 A, 553-560 (1980).

182) A. Van Wormhoudt: Marine Biology, 19 , 245-249 (1973).

183) A. Van Wormhoudt and D. Sellos: Oceanol. Acta, 3, 97-105 (1980).

184) A. LAUBIER-BONICHON, A. Van WORMHOUdT, and D. Sellos: 3r3 ICES Working Group Maric. Brest. Actes Coll. CNEXO, 4, 85-91 (1977).

185) E. Alliot, A. Pastoureaud, and J. Trellu: 3rd ICES Working-Group Maric. Brest. Actes Coll. CNEXO, 4: 85-91 (1977).

186) J. Trellu, J. Albertini-Berhaut, and H. J. Ceccaldi: Biochem. Syst. Ecol., 6, 265-259 
(1978)

187) H. Boulekbache, L. H. Devillers, A. J. RosenBERD, and C. L. JolY: C. R. Acad. Sci. Paris. D, 268, 2211-2216 (1969).

188) M.-T. Thebault and A. Bernicard: Comp. Biochem. Physiol., 61 B, 379-384 (1978).

189) P. RiChard and H. J. CeCCALDI: 3rd Meeting I.C.E.S., Working Group on mariculture, Actes, Coll. CNEXO, 4, 203-212 (1972).

190) H. J. Ceccaldi and F. Trellu: C. R. Soc. Biol., 1249-1255 (1975).

191) J. R. Franck, J. B. Sulkin, and R. P. Morgan: Marine Biology, 32, 105-111 (1975).

192) H. IsHoxa: Bull. Nansei Reg. Fish. Res. Res. Lab., 6, 59-84 (1973).

193) J. Trellu and H. J. Ceccaldi: C. R. Soc. Biol. 171, 115-120 (1977).

194) W. H. Sutcliffe: J. Fish. Res. Bd. Canada, 27, 606-609 (1970).

195) F. J. Bulow: J. Fish. Res. Bd Canada, 27, 2343-2349 (1970).

196) M. J. Dagg and J. L. Littlepage: Mar. Biol., 17, 162-172 (1972).

197) R. A. HaInes: J. Fish. Res. Bd. Canada, 30, 195-199 (1973).

198) M. Regnault and P. Luquet: Mar. Biol., 25, 291-298 (1974).

199) S. D. Sulkin, R. P. Morgan, and L. L. MinaSIAN Jr: Mar. Biol. 32, 113-117 (1975).

200) G. Moreau, Y. Henoceue, A. Van Wormhoudt, B. J. Martin and H. J. Ceccaldi: Abstr. Pap. World Maric. Soc. Soc. Venise, 21-25 (1981).

201) F. M. Mc Corkle, J. E. Chambers, and J. D. Yarbrough: Comp. Biochem. Physiol., 62 B, 151-153 (1979).

202) M. FlorkIN and E. SchoffenIels: Molecular approches to ecology, Acad. Press, New York, 1-203 (1969).

203) R. Gilles: Annls. Soc. Roy. Belg. 97, 31-34 (1967).

204) E. Schoffeniels: Archs. int. Physiol. Biol., 76 319-343 (1968).

205) P. W. HochachKA and G. N. SOMERo: in "Fish Physiology" (ed. by W. S. HoAR and D. J. RANDALL), Vol. 6, Academic Press. New York, 1972, pp. 100-156.

206) P. W. HochachKa and G. N. Somero: Strategies of biochemical adaptation, Saunders, Philadelphia (1973).

207) J. Hazel and C. L. Prosser: Physiol. Rev., 54, 620-677 (1974).

208) J. DAs and C. L. Prosser: Comp. Biochem. Physiol, 21, 441-467 (1967).

209) W. B. Verneerg: Comp. Biochem. Physiol., 26, 499-508 (1968).

210) J. Baldwin: Comp. Biochem. Physiol., 40, 181-187 (1971).

211) H.W. Behrish: Biochem. J., 121, 399-409
(1971).

212) J. D. Kent and R. G. Hart: Comp. Biochem. Physiol., 54 B, 77-80 (1976).

213) J. I. Narita and S. HochIURI: Comp. Biochem. Physiol., 64 B, 249-254 (1979).

214) L. F. BorkenhaGeN and F. P. KenNEDY: $J$. Biol. Chem., 227, 951-960 (1957).

215) R. S. Caldwell and J. F. Vernberg: Comp. Biochem. Physiol., 34, 179-185 (1970).

216) E. WodkTE. Biochem. Biophys. Acta, 529, 280289 (1978).

217) B. J. MaRTIN and H. J. Ceccaldi: Biochem. Syst. Ecol., 5, 151-154 (1977).

218) Y. A. Fontaine: Biochem. Biophys. Perspect. Mar. Biol, , 2, 139-212 (1975).

219) H. Perrier and C. Perrier: Comp. Biochem., Physiol., 63 A, 481-482 (1979).

220) H. Perrier, G. Llaurens, C. Perrier, G. Peres and J. Gras: Rev. Can. Biol., 39, 141-147 (1980).

221) J. Trellu and H. J. Ceccaldi, Biochem. Syst. Ecol., 8, 171-179 (1980).

222) S. Bricteux-Gregoire, G. Duchateau-Bosson, C. Jeuniaux, and M. Florkin: Archs. int. Physiol. Bioch., 72, 835-842 (1964).

223) A. E. Chaplin, A. K. Huggins, and K. A. Munday: Comp. Biochem. Physiol., 16, 4962 (1965).

224) Z, P, ZEIN ElDIN: Biol, Bull., 125, 188-196 (1963),

225) J. R. Sargent, A. J. Thomson, M. H. Dalgleish, and A, D, DAlE: Proc, 9t $h^{*}$ Europ mar, biol., Symp, , 463-474 (1975).

226) R. TANaka and A. Teruya: Biochim. Biophys. Acta, 323, 584-591 (1973).

227) N.Y.S. Woo and J.C. MURAT: Marine Biology, 61, 255-260 (1981).

228) A. M. Farghaty, A. A. Ezzat, and M. B. Shabana: Comp. Biochem. Physiol, 46 A, 183193 (1973).

229) N. Abdul-MalaK: Etude au moyen de radiotraceurs du métabolisme des phospholipides des tissus de la truite arc-en-ciel Salmo irideus. Effect de la salinité et de la température. Thèse Doctorat d'Etat. Université Claude Bernard Lyon I, 217 p. (1978).

230) R. Meister: Etude des lipides branchiaux, hépatiques et musculaires chez l'anguille adaptée à l'eau de mer ou à l'eau douce. Thèse Doctorat 3ème cycle. Univer sité Claude Bernard Lyon I, 86 p. (1971).

231) A. Van Wormhoudt and H. J. Ceccaldi: 10th Europ. Symp. Mar. Biol. Ostend, 1, 505-521 (1975).

232) M. H. Barahona-Fernandes: Aquaculture, 17, 311-321 (1979).

233) J. Trellu and H. J. Ceccaldi: Biochem. Syst. Ecol. 6, 181-191 (1980). 
234) R. J. Thompson, C. J. BAYNe, M. M. MOORE, and T. H. Carefoot: J. comp. Physiol., 127, 287-298 (1978)

235) M. I. Grossman, M. Grondard, and I. C. IVY: Ann. J. Physiol., 138, 676-682 (1942).

236) G. Marchis-Mouren, L. Passero, and P, Desnuelle: Biochem. Biophys. Res Comm., 13, 262-266 (1963).

237) A. Ben Abdelulil and P. Desnuelle: Biochem. Biophys. Acta., 80, 136-149 (1964).

238) P. A. GabBot and B. L. BAYNe: J. mar. Biol. Assoc. U. K., 53, 269-286 (1973).

239) A. Furukawa: Proceed. First intern. Conf. on Aquac. Nutr., 85-104 (1975).

240) T. Onishi, M. Suzuki, and M. TakeUchi: Bull. Japan. Soc. Sci. Fish., 47, 353-357 (1981).

241) A. Van Wormhoudt, H. J. CecCALd, and B. J. MARTIN: Aquaculture, 21, 63-78 (1980).

242) A. Bonichon-Laubier: C. $R$. Acad. Sci. Paris., D., 281, 2013-2016, (1975).

243) P. Calow: Biol. Rev., 54, 23-40 (1979).

244) S. Konosu, K. YamaguchI, and T. HaYashI: Bull. Japan. Soc. Sci. Fish., 44, 505-510 (1978).

245) T. Hayashi, K. Yamaguchi, and S. Konosu: Bull. Japan. Soc. Sci. Fish., 44, 1357-1362 (1978).

246) T. Hayashi, A. Asakawa, K. Yamaguchi, and S. Konosu: Bull. Japan. Soc. Sci. Fish., 45, 1325-1350 (1979).

247) M. Fingerman: Life Science, 14, 1007-1018 (1974).

248) S. U. Silverthorn: Comp. Biochem. Physiol, 45 A, 417-420 (1973).

249) N. TIlger and A. LesickI: Comp. Biochem. Physiol., 54 B, 111-115 (1976).

250) A. Van Wormhoudt, C. Bellon-Humbert, and Malcoste: Arch. Zool. exp. gên., 117, 451468 (1976).

251) F. Van Herp, C. Bellon- umbert, J. R. M. LuUB, and A. Van WormhoudT: Arch. Biol. (Bruxelles), 88, 257-278 (1978).

252) S. Hisano: J. Fac. Sci. Hokkaido Univ. Ser VI. Zool., 20, 167-174 (1976).

253) S. Hisano: Cell. Tiss. Res., 166, 511-520 (1976)

254) P. M. Andrews, D. E. Copeland and $M$. Frngerman: $\quad Z$. Zellforsch., 113, 461-471 (1971)

255) G. E. Strolenberg, C. Bellon, F. Van Herp, and A. Van Wormhoudr: C. R. Acad. Sci. Paris. D, 284, 123-125 (1977).

256 G. E., Strolenberg, F. Van Herp, A. Van WorMHoudt, and C. Bellon-Humbert: Abstr. pap. 8tr Int. Symp. Comp. Endocr., 150 (1978).

257) A. Van Wormhoudt, C. Bellon, and A. Le Roux: Gen. Comp. Endocr., 35, 263-273 (1978).

258) D. Sellos and A. Van Wormhoudt: Biochimie, 393-404 (1979).

259) D. Sellos, A. Van Wormhoudt, and Y. Le GAL: C. R. Acad. Sci. Paris D, 284, 489-492 (1977).

260) J. L. Gorgels-KelleN and F. Van Herp: $J$.
Morphol., 170, 347-355 (1981).

261) L. H. KLeInholz: Ann. Zool., 16, 151-166 (1976).

262) G. K. Kulkarni and R. Nagabushanam: Aquaculture, 19, 13-19 (1980).

263) J. A. KELEMEC and I. R. SMTth: Aquaculture, 21, 55-62 (1980).

264) K. Ragavaiah, R. Ramamurthi, V. Chandra Sekharam, and B. T. SCHeER: Comp. Biochem. Physiol., 67 B, 437-445 (1980).

265) R. Ramamurthi, K. Raghavaiah, V. Chandra Sekharam, and B. T. Scheer: Comp. Biochem. Physiol., 71 B, 223-228 (1982).

266) P. FERLund and L. Josefsson: Science, 177, 173-175 (1972).

267) F. Yamazaki and E. M. Donaldson: Gen. Comp. Endocr., 10, 383-391 (1968).

268) B. JALABERT, B. BRETON, and R. BILLARD: ANN Biol., Anim. Biochim. Biophys., 14: 217-226 (1974).

269) D. R. IDLER, L. S. BAZAR, and J. S. HwANG: Endocr. Res. Comm., 2, 215-235 (1975).

270) H. P. Clemens and F. B. Grant: Copeia, 2, 174-177 (1965).

271) E. M. Donaldson, F. Yamazaki, H. M. Dye, and W. W. Philleo: Gen. Comp. Endocr., 18, 469-481 (1972).

272) K. Hirose and R. IsHida: Bull. Japan. Soc. Sci. Fish., 40, 1235-1240 (1974).

273) A. J. W. Hsuer and G. F. Erickson: Science, 204, 854-855 (1979).

274) R. BILlARD and J. MARCEL: Aquaculture, 21, 181-195 (1980).

275) R. F. Uglow: Comp. Biochem. Physiol., 31, 970-973 (1969).

276) J. E. Stewart and B. ArIE: Canad. J. Microbiol., 19, 1103-1110 (1973).

277) J. E. Stewart and W. CorniY: Canad. J. Microbiol., 18, 1511-1543 (1972).

278) J. E. Stewart and B. ArIE: Comp. Biochem. Physiol, 45 A, 717-730 (1973).

279) C. P. Vivares, J. Trellu, and H. J. Ceccaldi: Experientia, 33, 1311-1312 (1977).

280) C. P. Vivares and J.-L. CuQ: J. Invert. Pathol, 37, 38-46 (1981).

281) D. V. Lightner: Proceed. 3rd US-Japan Meet. Aquac. Tokyo. Spec. Publ. Fish. Agency and Japan Sea Reg. Fish. Res. Lab. $75-97$ (1975).

282) J. A. HufF and C. D. Burns: Aquaculture, 22, 181-184 (1981)

283) C. P. Vivares, J.-L. Clq, H. J. Ceccaldi, and P. J. RICHARD: J. exp. mar. Biol. Ecol. 43, 207-220 (1980).

284) C. P. Vivares, P. Richard, and H. J. Ceccaldi. Fourth. Internat. Congr. Parasitol Warsawa Poland, Worksh 3, 47 (1978).

285) C. P. Vivares, P. Richard, and H. J. Ceccaldi. Biochem Syst. Ecol., 8, 205-209 (1980). 
286) H. J. Ceccaldi: Oceanis, 7, 489-509 (1981).

287) A. Kanazawa and S. Teshima: Bull. Japan. Soc. Sci. Fish, 47 1375-1377 (1981).

288) S. Ieshima, A. Kanazawa, M. Kamezaki, and H. Hirata: Bull. Japan. Soc. Sci Fish., 47, 515-522 (1981).

289) A. Hino and R. Hirano: Bull. Jap. Soc. Sci. Fish., 46, 1217-1222 (1980).

290) S. FuKe, S. Konosu, and K. INA: Baull. Japan.
Soc. Sci. Fish. 47, 1631-1636 (1981).

291) C. P. Vivares, B. J. Martin, and H. J. CeCCaldo Z. Parasitenkd., 61, 99-107 (1980).

292) D. RoDRIGUEZ, A. VAN WORMHOUdT and Y. Le Gal: Comp. Biochem. Physiol., 54 B, 181191 (1976).

293) R. E. Catalan, A. M. Martinez, and M. D. Aragones: Comp. Biochem. Physiol., 71 B 301303 (1982). 